\title{
Satisfaction Levels of Insured Apricot Producers towards Agricultural Insurance Services
}

\author{
Mehmet Hasdemir ${ }^{1} \&$ Hasim Ozudogru ${ }^{2}$ \\ ${ }^{1}$ Republic of Turkey Ministry of Food, Agriculture and Livestock General Directorate of Plant Production, \\ Ankara, Turkey \\ ${ }^{2}$ School of Banking and Insurance, Gazi University, Ankara, Turkey \\ Correspondence: Mehmet Hasdemir, Republic of Turkey Ministry of Food, Agriculture and Livestock General \\ Directorate of Plant Production, Eskişehir Yolu 9. Km Lodumlu, Ankara, Turkey. E-mail: \\ hasdemir44@gmail.com
}

Received: November 27, 2017

Accepted: December 31, 2017 Online Published: February 15, 2018

doi:10.5539/jas.v10n3p111

URL: https://doi.org/10.5539/jas.v10n3p111

\begin{abstract}
The objective of this research was to assess satisfaction levels of the insured farmers towards TARSIM agricultural insurance services. The study was conducted on the farmers engaged in apricot production in Malatya province of Turkey, the world's largest provider of apricots. About $69.88 \%$ of Turkey's dried apricot production and about $73.44 \%$ of the world dried apricot production are based in Malatya. Face-to-face interviews were conducted with a random sample of 187 farmers. Likert scale questionnaires were used to collect opinion data of farmers on five dimensions, namely sales and marketing, damage compensation, pricing and payment policy, customer notification and customer representation. Structural equation modeling was used to explore the association between the measured variables and overall satisfaction levels. The results of structural equation modeling indicated that all dimensions had statistically significant effects on farmer satisfaction. Additionally, according to the standard estimations, satisfaction from sales and marketing, satisfaction from customer notification and satisfaction from damage compensation were the most significant determinants of customer satisfaction. Pricing and payment policy had the lowest influence on farmer satisfaction. The study results showed that efficient and rapid resolution of farmer problems and grant of ease for premium payments were the most influential factors affecting farmer satisfaction.
\end{abstract}

Keywords: apricot, insurance, TARSIM, satisfaction, structural equation modeling

\section{Introduction}

Global climate change and price fluctuations in food markets severely affect agricultural sector and increase risks and uncertainties. The world is facing the problem of decreasing stocks of natural resources, in particular arable land and water per capita. In this context, it is required to adopt sustainable natural resource management practices and efficient planning strategies which will eliminate or mitigate the foreseen potential risks (Anonymous, 2014). Fourth Assessment Report of the Intergovernmental Panel on Climate Change (IPCC) projects that in the next century, warming rates will increase in the Mediterranean Region which includes Turkey, rainfall will decrease by $20 \%$, soil humidity will be reduced and sea levels will be rising. These changes are estimated to result losses and damages in agricultural lands and decrease in crop yields (Anonymous, 2007).

Turkey has a robust agriculture industry due to its agro-ecological zoning. Hence, it is one of the most important actors of world food industry as a producer and importer of many agricultural products. Apricot is one of the exported products of Turkey. According to the latest data of Food and Agriculture Organization of the United Nations; Turkey accounted for $18.97 \%$ of 4.1 million tonnes of world apricot production by 2013 , and $73.44 \%$ of 138,000 tonnes of world apricot export by 2012 (FAO, 2015). 69.88\% of Turkey's dried apricot production is based in Malatya. In the last 10 year interval between 2004-2014, Turkey's apricot production ranged between 860,000-270,000 tonnes (TURKSTAT, 2015). The annual rates of change in production have been fluctuating between $-65.38 \%$ and $-168.75 \%$ in the last 10 years. The most important reason of the decline in Turkey's apricot production is spring frost hardiness during the bloom period of apricot cultivars in the orchards of Malatya (Güneş, 2006; Kaska, 2006). Substantial fluctuations in apricot production led by natural disasters have negative impacts 
on socio-economic conditions of the farmers who rely on agriculture for their livelihoods and the economic growth of the country.

Agricultural insurance, which was originally started simply as hail insurance, was started to be implemented in Turkey in 1957 within the scope of the Insurance Law. "Risk Management in Agriculture" gained increasing momentum with the adoption of Agricultural Insurance Law (No. 5363) in 2005 which determined the procedures and principles regarding the implementation of agricultural insurance in order to compensate farmers for losses occurring due to the risks set out in the Law. As stipulated by the Law, Turkish Agricultural Insurance Pool (TARSIM) was established and state supported agricultural insurance policies were started to be issued as of 2006 (Anonymous, 2014).

Significant increases were recorded in the issuance of insurance policies with the implementation of state supported agricultural insurance. While a total of 12,330 agricultural insurance policies were issued in 2006, this number increased to over 1 million in 2014. Accordingly, insurance premiums and compensation costs have also increased significantly. Premiums and compensation costs which amounted about 4.46 million TL and 868,000 TL in 2006 increased to 684 million TL and 502 million TL in 2014, respectively. The insurance covers quantity loss of all crops due to hail, storm whirlwind, fire, earthquake, landslide and flood and quality loss of fresh fruits/vegetables and cut flowers due to hail (TARSIM, 2015).

The losses in apricot production caused by natural disasters and the resulting fluctuations in crop yield were also reflected in the numbers of apricot insurance policies of TARSIM. The number of apricot insurance policies was 9,825 in 2010 in Turkey which increased to 14,139 in 2011, 13,006 in 2012 and then decreased to 9,848 in 2013. In the year 2014 which was hit by significant frost damage, the number of apricot insurance policies reached to 18,080 with an $83.6 \%$ increase compared to previous year (TARSIM, 2014). The development of agricultural insurances provides significant contributions to the management of apricot production sector which is subject to high level of risks and uncertainties. Customer satisfaction is an important factor affecting the improvement of insurance business. The satisfaction of apricot producers who are customers of TARSIM significantly influences the decision of these producers on risk management. The satisfaction towards a state supported agricultural insurance system is not only important for the beneficiaries but also for the parties and policy-makers who allocate state funding for provision of these services.

Customer perception or in other words, customer satisfaction, is one of the most important strategies for the enterprises. Many researchers define customer satisfaction as the comparison of pre-purchase expectations with post-purchase perceptions which shapes the value and attitude of the customer towards the purchased product/service (Saha \& Zhao, 2005; Oliver, 1980; Gençtürk et al., 2011). Due to intense competition and contemporary marketing vision in a dynamic market environment, customer satisfaction is the focal point of all marketing activities. Taking and implementing customer satisfaction oriented decisions can only be possible with awareness on customer behaviours (Tak, 2002; Eroğlu, 2005).

\section{Materials and Methods}

The objective of this study was to assess the satisfaction levels of the insured farmers towards TARSIM apricot insurance services. In this study, it was hypothesized that sales and marketing, damage compensation, pricing and payment policy, customer notification and customer representation have significant influence on customer satisfaction.

\subsection{Sampling Method}

The study was conducted on the farmers engaged in apricot production in Malatya province of Turkey, where about $69.88 \%$ of Turkey's dried apricot production and about $73.44 \%$ of the world dried apricot production are based (Anonymous, 2015; FAO, 2012). According to the data of Farmer Registration System (FRS) of the Ministry of Food, Agriculture and Livestock, there are 33,926 farmers engaged in apricot production in Malatya province.

The sample size was determined for the specified sensitivity and confidence level in accordance with the total population size based on the equation below (Yamane, 2009):

$$
n=\frac{N\left(z s^{2}\right)}{N d^{2}+\left(z s^{2}\right)}
$$

Where, $N=$ population size, $z=$ critical value at standard normal distribution corresponding to the specified confidence level, $d=$ sensitivity, $s=$ standard deviation. If the sample size is proportional to the size of the population, the variance of the sample proportion is estimated by: $S^{2}=p \cdot q ;(q=1-p)$, and Equation (1) is expressed as below: 


$$
n=\frac{N z^{2} p q}{N d^{2}+z^{2} p q}
$$

Based on this formula, the sample size was calculated as 170 out of a population of 33,926 apricot producers for $95 \%$ confidence level and $7.5 \%$ sensitivity. The farmers to be surveyed were selected randomly and a total of 187 farmers were interviewed face-to-face in 2014.

\subsection{Method for Data Analysis}

Satisfaction was measured at five dimensions using a likert scale format. The scale of satisfaction towards TARSIM agricultural insurance was developed based on the parameters used in insurance customer satisfaction studies the studies and opinions of insurance experts.

\subsection{Reliability and Validity Analysis}

Cronbach's Alpha coefficient was calculated to assess reliability and validity of the survey data and hypotheses of the factor research were tested with structural equation modeling. There are different methods used for estimation of reliability. Alpha Method (Cronbach's Alfa Coefficient) was used in this study. A coefficient value between 0.00 and 0.40 indicates that the scale is not reliable, a coefficient value between 0.40 and 0.60 indicates that the scale has low reliability, a coefficient value betwen 0.60 and 0.80 indicates that the scale is fairly reliable and a coefficient value between 0.80 and 1.00 indicates that the scale is highly reliable (Akgül \& Çevik, 2003).

In order to test the applicability of factor analysis to scale items (i.e. to assess whether scale items can be grouped under one or more factors) Bartlett test is performed. The p value of Bartless test below 5\% indicates that the scale items have internal consistency and it is appropriate to continue with factor analysis. KMO (Kaiser-Meyer-Olkin) coefficient is used to assess the adequacy of the sample size for factor analysis. A coefficient value above 0.50 indicates that the sample size is adequate for factor analysis. The higher is the variance ratio, the stronger is the factor structure of the scale. Explained variance values between $40 \%$ through $60 \%$ are considered acceptable in social sciences (Scherer, Wieb, Luther, \& Adams, 1988).

\subsection{Structural Equation Modeling}

In order to assess the satisfaction towards the services of TARSIM on different dimensions, the expressions in Table 6 were addressed to the interviewees. All ratings were made on Likert-scale from 1 to 5 . Structural equation modelling was used to estimate the relationship between the ratings on scale items and overall satisfaction towards agricultural insurance services. Structural equation modeling is a multivariate statistical method used to test a pre-determined relationship and to explore the effects of observed variables on latent (factoral dimension) variable. CMIN (the ratio of chi-square to degrees of freedom) and RMSEA values are the commonly used fit indices for structural equation modeling. A CMIN value between 0 and 3 and a RMSEA value between 0 and 0.10 indicate acceptable fit between the model and the survey data (Schermelleh-Engel et al., 2003).

\section{Results and Discussion}

In a sector where risk management is crucial, purchase of agricultural insurance is highly important to enable farmers manage risks and maintain sustainability of their production. Previous studies on agricultural insurance were mostly focused on the identification of the factors affecting agricultural insurance purchase decisions by farmers. The findings of these research generally revealed the effects of farmer characteristics such as educational background, age, level of income, size of enterprise, land use pattern and the effects of enterprise characteristics on agricultural insurance purchase decisions by farmers (Gül Yavuz, 2011; Kumar et al., 2011; Tümer, 2011; Dragos \& Codruta, 2014). These findings constitute valuable inputs for determination of strategies to proliferate agricultural insurance programs.

Demographic characteristics of the surveyed farmers are presented in Table $1.4 .81 \%$ of the farmers are female and $95.19 \%$ are male. $30.48 \%$ of the farmers are aged $25-45,20.32 \%$ are aged $46-52$ and $49.20 \%$ are aged $53-86$. $43.85 \%$ of the farmers are graduated from primary school, $22.46 \%$ are graduated from high school, $13.37 \%$ are graduated from secondary school and $6.95 \%$ are university graduates. $10.70 \%$ of the surveyed farmers are literate while $2.67 \%$ is illiterate. The findings indicated that the majority of the farmers are aged above 50 and have an educational background below high school level.

$48.66 \%$ of the farmers have an additional source of income besides that obtained from apricot production. For $19.25 \%$ of the farmers, income from apricot production constitutes $80-100 \%$ of the total income; for $20.86 \%$ of the farmers, income from apricot production constitutes $60-80 \%$ of the total income; for $23.53 \%$ of the farmers, income from apricot production constitutes $40-60 \%$ of the total income; and for $16.04 \%$ of the farmers, income from apricot production constitutes less than $20 \%$ of the total income. 
Table 1. Demographic characteristics of surveyed farmers

\begin{tabular}{|c|c|c|c|}
\hline Characteristics & & Number & Percent (\%) \\
\hline \multirow[t]{2}{*}{ Sex } & Female & 9 & 4.81 \\
\hline & Male & 178 & 95.19 \\
\hline \multirow[t]{4}{*}{ Age } & $25-45$ age group & 57 & 30.48 \\
\hline & 46-52 age group & 38 & 20.32 \\
\hline & 53-62 age group & 46 & 24.60 \\
\hline & 63-86 age group & 46 & 24.60 \\
\hline \multirow[t]{6}{*}{ Educational background } & Illiterate & 5 & 2.67 \\
\hline & Literate & 20 & 10.70 \\
\hline & Primary school & 82 & 43.85 \\
\hline & Secondary school & 25 & 13.37 \\
\hline & High school & 42 & 22.46 \\
\hline & University & 13 & 6.95 \\
\hline \multirow[t]{2}{*}{ Having additional source of income } & No additional source of income & 96 & 51.34 \\
\hline & Has additional source of income & 91 & 48.66 \\
\hline \multirow{5}{*}{$\begin{array}{l}\text { The share of the income from apricot } \\
\text { production in total income }\end{array}$} & Below $20 \%$ & 30 & 16.04 \\
\hline & $20 \%-40 \%$ & 38 & 20.32 \\
\hline & $40 \%-60 \%$ & 44 & 23.53 \\
\hline & $60 \%-80 \%$ & 39 & 20.86 \\
\hline & $80 \%-100 \%$ & 36 & 19.25 \\
\hline
\end{tabular}

$39.04 \%$ of the surveyed farmers have previously purchased agricultural insurance while $60.96 \%$ have not purchased any agricultural insurance in the past. By the survey year of 2014, it was recorded that $45.99 \%$ of the farmers did not have any insurance whereas $54.01 \%$ were already insured. The insurances covered the risks of frost and hail. $31.02 \%$ of the farmers were insured only against the risk of frost, $7.49 \%$ were insured only against the risk of hail and $15.51 \%$ were insured against both risks (Table 2).

Table 2. Insurance status of surveyed farmers

\begin{tabular}{llll}
\hline & & Number & Percent (\%) \\
\hline Purchase of insurance in the past & Purchased & 73 & 39.04 \\
& Not purchased & 114 & 60.96 \\
\hline Insurance status by the survey year (2014) & Uninsured & 86 & 45.99 \\
& Frost insurance & 58 & 31.02 \\
& Hail insurance & 14 & 7.49 \\
& Frost and hail insurance & 29 & 15.51 \\
\hline
\end{tabular}

In parallel with apricot production statistics, $97.33 \%$ of the surveyed farmers declared that their crops have been damaged in the last 3 years. $71.93 \%$ of the insured farmers have received their compensations from TARSIM in the last 3 years (Table 3 ).

Table 3. Crop damage and compensation status of surveyed farmers

\begin{tabular}{llll}
\hline & & Number & Percent (\%) \\
\hline Crops damage in the last 3 years & Yes & 182 & 97.33 \\
& No & 5 & 2.67 \\
& Total & 187 & 100.00 \\
\hline Receiving compensation from TARSiM & Yes & 82 & 71.93 \\
& No & 32 & 28.07 \\
& Total & 114 & 100.00 \\
\hline
\end{tabular}


The reasons for not purchasing agricultural insurance declared by the farmers who were uninsured as of 2014 are given in Table 4. As indicated in the table, high premiums $(74.42 \%)$ were the most important reason that deterred farmers from purchasing agricultural insurance. While inheritance and succession issues were the main reason for $12.79 \%$ of the farmers for not purchasing insurance, $9.30 \%$ stated that they missed the deadline for purchase of insurance.

Table 4. Reasons that deter farmers from purchasing agricultural insurance

\begin{tabular}{lll}
\hline & Number & Percent (\%) \\
\hline No risks of natural disasters in the orchard, gets crop every year & 5 & 5.81 \\
The orchard is not registered under FRS & 7 & 8.14 \\
High premiums & 64 & 74.42 \\
Inheritance and succession issues & 11 & 12.79 \\
Missed deadline for purchase of insurance & 8 & 9.30 \\
Other & 10 & 11.63 \\
Total & $\mathbf{8 6}$ & $\mathbf{1 0 0}$ \\
\hline
\end{tabular}

$33.16 \%$ of the surveyed farmers reported that they do not consider purchasing agricultural insurance in 2015. $32.09 \%$ of the farmers consider purchasing hail insurance, $5.88 \%$ consider purchasing frost insurance and $28.88 \%$ consider purchasing both (Table 5).

Table 5. Opinions of surveyed farmers on purchasing agricultural insurance in 2015

\begin{tabular}{lll}
\hline & Number & Percent (\%) \\
\hline Will not purchase insurance & 62 & 33.16 \\
Frost insurance & 11 & 5.88 \\
Hail insurance & 60 & 32.09 \\
Both & 54 & 28.88 \\
Total & $\mathbf{1 8 7}$ & $\mathbf{1 0 0 . 0 0}$ \\
\hline
\end{tabular}

Cronbach's Alpha coefficient for the survey data was calculated as 0.955 . This value indicates that the scale is highly reliable.

The results of reliability and validity analysis of the survey scale are given in Table 6 . As seen from the table, the loading values of each scale item on the respective dimension and values of Cronbach's Alpha coefficients are high. The higher is the variance ratio, the stronger is the factor structure of the scale. 
Table 6. The results of reliability and validity analysis of the scale items on farmer satisfaction towards TARSIM services

\begin{tabular}{|c|c|c|c|c|}
\hline \multicolumn{2}{|c|}{ Services provided and farmer satisfaction } & \multirow{2}{*}{$\begin{array}{l}\begin{array}{l}\text { Factor } \\
\text { Loadings }\end{array} \\
0.816\end{array}$} & \multirow{2}{*}{$\begin{array}{l}\text { Average } \\
2.99\end{array}$} & \multirow{2}{*}{$\begin{array}{l}\text { Std. Dev. } \\
1.297\end{array}$} \\
\hline Sales and marketing services & S.1:The coverage of the insurance policy is explained clearly & & & \\
\hline & S.2: Insurance needs are correctly defined & 0.864 & 3.09 & 1.184 \\
\hline & $\begin{array}{l}\text { S.3: Insurance policy is prepared and delivered } \\
\text { in a timely manner }\end{array}$ & 0.588 & 3.68 & 0.924 \\
\hline & S.4:TARSIM is a reliable insurance company & 0.742 & 3.36 & 1.226 \\
\hline & S.5:Insurance policy meets my expectations & 0.739 & 2.69 & 1.213 \\
\hline & \multicolumn{4}{|c|}{ A.Variance (\%): 57.120; Cronbach's Alpha: 0.810; KMO: 0.756; Bartlett's Test: $225.454(p=0.000)$} \\
\hline \multirow[t]{5}{*}{ Damage compensation services } & $\begin{array}{l}\text { H.1:I can quickly reach to the insurance company } \\
\text { in case of damage }\end{array}$ & 0.704 & 3.41 & 1.119 \\
\hline & $\begin{array}{l}\text { H.2: The company shows an expert positive approach } \\
\text { towards damage }\end{array}$ & 0.759 & 3.43 & 1.200 \\
\hline & H.3:Damage compensation is provided in a timely manner & 0.745 & 3.31 & 1.106 \\
\hline & $\begin{array}{l}\text { H.4: I can easily access to the information on damage } \\
\text { compensation procedures }\end{array}$ & 0.867 & 3.33 & 1.067 \\
\hline & A.Variance (\%): 59.500; Cronbach's Alpha: 0.768; KMO: 0.727; & Bartlett's $T_{e}$ & st: 140.902 & $=0.000)$ \\
\hline \multirow[t]{5}{*}{ Pricing and payment policy } & F.1: I am pleased with TARSIM's pricing policy & 0.622 & 2.13 & 1.190 \\
\hline & F.2: I am pleased with the payment system & 0.834 & 3.21 & 1.112 \\
\hline & F.3: The company grants ease for premium payment & 0.900 & 3.19 & 1.079 \\
\hline & F.4: Payment receipts are sent in a timely manner & 0.817 & 3.22 & 0.983 \\
\hline & A.Variance (\%): 64.000; Cronbach's Alpha: 0.800; KMO: 0.699; & Bartlett's Te & st: 206.321 & $=0.000)$ \\
\hline \multirow[t]{5}{*}{$\begin{array}{l}\text { Notification on insurance } \\
\text { policy and collateral warranties }\end{array}$} & $\begin{array}{l}\text { B.1: Our demands on changes to insurance policy and } \\
\text { such similar are taken into consideration }\end{array}$ & 0.821 & 2.88 & 1.148 \\
\hline & $\begin{array}{l}\text { B.2: I am informed on the coverage of the insurance policy } \\
\text { and my legal rights }\end{array}$ & 0.808 & 2.83 & 1.258 \\
\hline & $\begin{array}{l}\text { B.3: Our insurance policy-related problems are resolved } \\
\text { in a timely manner }\end{array}$ & 0.935 & 3.02 & 1.127 \\
\hline & $\begin{array}{l}\text { B.4: I can get information on the insurance policy } \\
\text { whenever I want }\end{array}$ & 0.798 & 3.25 & 1.042 \\
\hline & A.Variance (\%): 70.960; Cronbach's Alpha: 0.860; KMO: 0.758; & Bartlett's Te & st: 266.380 & $=0.000)$ \\
\hline \multirow[t]{6}{*}{ Customer representation } & T.1: I can reach to the customer representative whenever I want & 0.798 & 3.30 & 1.111 \\
\hline & $\begin{array}{l}\text { T.2: The customer representative provides all the necessary } \\
\text { and precise information on my insurance-related problems }\end{array}$ & 0.881 & 3.18 & 1.067 \\
\hline & $\begin{array}{l}\text { T.3: The customer representative closely follows up the } \\
\text { procedures pertaining to my demands and complaints }\end{array}$ & 0.894 & 3.01 & 1.015 \\
\hline & $\begin{array}{l}\text { T.4: The customer representative creates alternative solutions } \\
\text { for my needs and problems }\end{array}$ & 0.855 & 2.89 & 1.080 \\
\hline & $\begin{array}{l}\text { T.5: The customer representative is equipped with } \\
\text { sufficient technical knowledge }\end{array}$ & 0.862 & 2.91 & 1.210 \\
\hline & A.Variance (\%): 73.720; Cronbach's Alpha: 0.909; KMO: 0.836; & Bartlett's $T_{\epsilon}$ & st: 437.769 & $=0.000)$ \\
\hline
\end{tabular}

The graphical illustration of the structural equation modeling for satisfaction towards agricultural insurance services is given in Figure 1. 


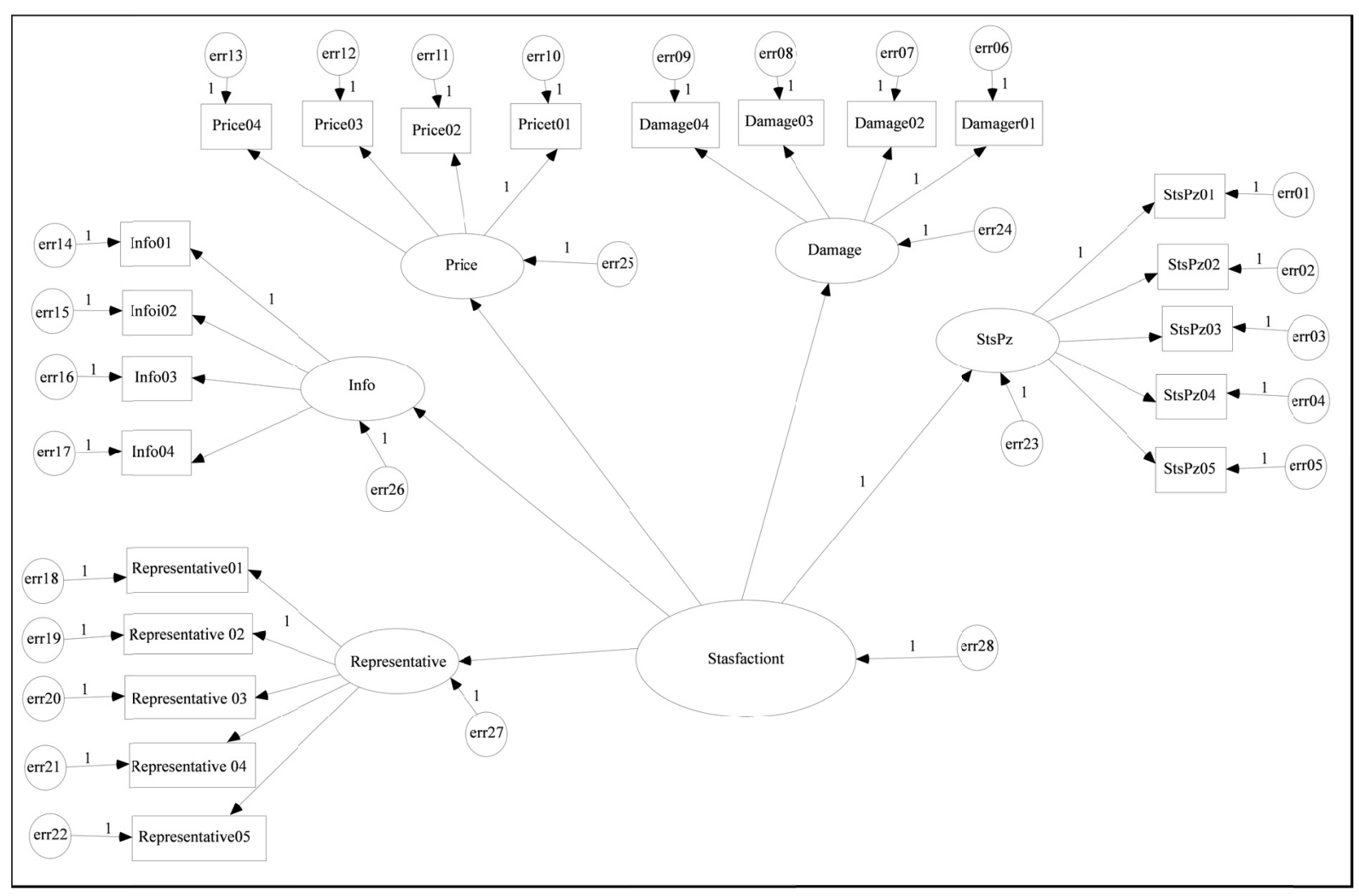

Figure 1. Graphical illustration of the structural equation modeling for satisfaction towards agricultural insurance services

The estimation of the effect of satisfaction dimensions on overall satisfaction is given in Table 7. The table indicates that all dimensions had statistically significant effects on customer satisfaction. Additionally, according to the standard estimations, satisfaction from sales and marketing, satisfaction from customer notification and satisfaction from damage compensation were the most significant determinants of farmer satisfaction towards agricultural insurance. Pricing and payment policy had the lowest influence on farmer satisfaction.

Table 7. The estimation of the effect of satisfaction dimensions on overall satisfaction

\begin{tabular}{|c|c|c|c|c|c|}
\hline Services & Estimate & S.H. & K.D. & $\mathbf{P}$ & Std. Estimate \\
\hline Sales and marketing services & 1 & & & & 0.88 \\
\hline Damage compensation services & 0.766 & 0.118 & 6.514 & $* * *$ & 0.885 \\
\hline Pricing and payment policy & 0.566 & 0.11 & 5.127 & $* * *$ & 0.811 \\
\hline Notification on insurance policy and collateral warranties & 0.882 & 0.119 & 7.392 & $* * *$ & 0.887 \\
\hline Customer representation & 0.729 & 0.107 & 6.814 & $* * *$ & 0.827 \\
\hline
\end{tabular}

The direct effects of the scale items on their respective dimensions and their indirect effects on overall satisfaction are presented in Table 8. As stated above, satisfaction from sales and marketing had the highest influence on farmer satisfaction. For the dimension on sales and marketing services, the scale item "S.1: The coverage of the insurance policy is explained clearly" was the most influential and the scale item "S.3: Insurance policy is prepared and delivered in a timely manner" was the least influential. This finding also shows that being clearly informed on the coverage of insurance policy is highly crucial for farmers. The low effect of the insurance policy delivery duration can be explained by the farmers' acceptance of the certain duration of delivery as per the legal procedures. 
Table 8 . The direct effects of the scale items on their respective dimensions and their indirect effects on overall satisfaction

\begin{tabular}{|c|c|c|c|c|c|c|c|}
\hline Services & & Estimate & S.H. & K.D. & $\mathbf{P}$ & Std. Estimate & Indirect effect \\
\hline \multirow[t]{5}{*}{ Sales and marketing services } & S.1 & 1 & & & & 0.78 & 0.686 \\
\hline & S.2 & 0.843 & 0.101 & 8.323 & $* * *$ & 0.724 & 0.637 \\
\hline & S.3 & 0.5 & 0.08 & 6.284 & $* * *$ & 0.556 & 0.489 \\
\hline & S.4 & 0.663 & 0.106 & 6.28 & $* * *$ & 0.559 & 0.492 \\
\hline & S.5 & 0.83 & 0.103 & 8.046 & $* * *$ & 0.699 & 0.614 \\
\hline \multirow[t]{4}{*}{ Damage compensation services } & H. 1 & 1 & & & & 0.688 & 0.609 \\
\hline & H.2 & 0.653 & 0.151 & 4.329 & $* * *$ & 0.427 & 0.377 \\
\hline & H.3 & 0.919 & 0.144 & 6.398 & $* * *$ & 0.641 & 0.567 \\
\hline & H.4 & 1.022 & 0.144 & 7.115 & $* * *$ & 0.738 & 0.653 \\
\hline \multirow[t]{4}{*}{ Pricing and payment policy } & F. 1 & 1 & & & & 0.503 & 0.408 \\
\hline & F.2 & 1.346 & 0.228 & 5.905 & $* * *$ & 0.762 & 0.618 \\
\hline & F.3 & 1.6 & 0.253 & 6.311 & $* * *$ & 0.908 & 0.736 \\
\hline & F.4 & 1.213 & 0.205 & 5.923 & $* * *$ & 0.766 & 0.621 \\
\hline \multirow{4}{*}{$\begin{array}{l}\text { Notification on insurance policy } \\
\text { and collateral warranties }\end{array}$} & B. 1 & 1 & & & & 0.77 & 0.683 \\
\hline & B. 2 & 1.008 & 0.119 & 8.444 & $* * *$ & 0.713 & 0.633 \\
\hline & B. 3 & 1.161 & 0.105 & 11.062 & $* * *$ & 0.911 & 0.808 \\
\hline & B. 4 & 0.909 & 0.099 & 9.173 & $* * *$ & 0.771 & 0.684 \\
\hline \multirow[t]{5}{*}{ Customer representation } & T.1 & 1 & & & & 0.722 & 0.597 \\
\hline & T.2 & 1.141 & 0.119 & 9.622 & $* * *$ & 0.829 & 0.685 \\
\hline & T.3 & 1.145 & 0.113 & 10.156 & $* * *$ & 0.883 & 0.73 \\
\hline & T.4 & 1.136 & 0.12 & 9.429 & $* * *$ & 0.824 & 0.681 \\
\hline & T.5 & 1.237 & 0.13 & 9.492 & $* * *$ & 0.81 & 0.67 \\
\hline
\end{tabular}

For the dimension on damage compensation services, the scale item "H.4: I can easily access to the information on damage compensation procedures" was the most influential and the scale item "H.2: The company shows an expert positive approach towards damage" was the least influential. This finding indicates that being well informed on their problem is the most important factor affecting farmer satisfaction towards damage compensation services.

For the dimension on pricing and payment policy, the scale item "F.3: The company grants ease for premium payment" was the most influential and the scale item "F.1: I am pleased with TARSIM's pricing policy" was the least influential. This finding indicates that grant of ease for premium payments is the priority of farmers.

For the dimension on notification on insurance policy and collateral warranties, the scale item "B.3: Our insurance policy-related problems are resolved in a timely manner" was the most influential and the scale item "B.2: I am informed on the coverage of the insurance policy and my legal rights" was the least influential. This finding indicates that rapid resolution of their problems is highly important for farmer satisfaction.

For the dimension on customer representation, the scale item "T.3: The customer representative closely follows up the procedures pertaining to my demands and complaints" was the most influential and the scale item "T.1: I can reach to the customer representative whenever I want" was the least influential. This finding indicates that the company's care of farmer considerations is highly important for farmer satisfaction. 
Table 9. The effects of scale items for satisfaction towards TARSIM

\begin{tabular}{|c|c|c|}
\hline Items or dimensions & Average & Std. Dev. \\
\hline S.1: The coverage of the insurance policy is explained clearly & 2.99 & 1.297 \\
\hline S.2: Insurance needs are correctly defined & 3.09 & 1.184 \\
\hline S.3: Insurance policy is prepared and delivered in a timely manner & 3.68 & .924 \\
\hline S.4: TARSIM is a reliable insurance company & 3.36 & 1.226 \\
\hline S.5: Insurance policy meets my expectations & 2.69 & 1.213 \\
\hline Sales and marketing services & 3.16 & .887 \\
\hline H.1: I can quickly reach to the insurance company in case of damage & 3.41 & 1.119 \\
\hline H.2: The company shows an expert positive approach towards damage & 3.43 & 1.200 \\
\hline H.3: Damage compensation is provided in a timely manner & 3.31 & 1.106 \\
\hline H.4: I can easily access to the information on damage compensation procedures & 3.33 & 1.067 \\
\hline Damage compensation services & 3.37 & .863 \\
\hline F.1: I am pleased with TARSIMM's pricing policy & 2.13 & 1.190 \\
\hline F.2: I am pleased with the payment system & 3.21 & 1.112 \\
\hline F.3: The company grants ease for premium payment & 3.19 & 1.079 \\
\hline F.4: Payment receipts are sent in a timely manner & 3.22 & .983 \\
\hline Pricing and payment policy & 2.94 & .864 \\
\hline B.1: Our demands on changes to insurance policy and such similar are taken into consideration & 2.88 & 1.148 \\
\hline B.2: I am informed on the coverage of the insurance policy and my legal rights & 2.83 & 1.258 \\
\hline B.3: Our insurance policy-related problems are resolved in a timely manner & 3.02 & 1.127 \\
\hline B.4: I can get information on the insurance policy whenever I want & 3.25 & 1.042 \\
\hline Notification on insurance policy and collateral warranties & 2.99 & .962 \\
\hline T.1: I can reach to the customer representative whenever I want & 3.30 & 1.111 \\
\hline $\begin{array}{l}\text { T.2: The customer representative provides all the necessary and precise } \\
\text { information on my insurance-related problems }\end{array}$ & 3.18 & 1.067 \\
\hline $\begin{array}{l}\text { T.3: The customer representative closely follows up the procedures pertaining to my } \\
\text { demands and complaints }\end{array}$ & 3.01 & 1.015 \\
\hline T.4: The customer representative creates alternative solutions for my needs and problems & 2.89 & 1.080 \\
\hline T.5: The customer representative is equipped with sufficient technical knowledge & 2.91 & 1.210 \\
\hline Customer representation & 3.06 & .940 \\
\hline Scale & 3.11 & .758 \\
\hline
\end{tabular}

When the indirect effects of scale items on overall farmer satisfaction are analyzed, the scale item "B.3: Our insurance policy-related problems are resolved in a timely manner" was the most influential and the scale item "F.3: The company grants ease for premium payment" was the second most influential. The scale items with the lowest influences were "H.2: The company shows an expert positive approach towards damage" and "F.1: I am pleased with TARSIM's pricing policy".

The averages indicated that the dimension farmers were least satisfied was pricing and payment policy (average: 2.94), and that farmers were most satisfied was damage compensation services (average: 3.37 ).

\section{Conclusion and Recommendations}

Considering the data on the insured farmers since 2006 - the starting date of state supported agricultural insurance policies - the identification of the factors affecting agricultural insurance purchase decisions by farmers and levels of farmer satisfaction are deemed to be crucial inputs for sustainability of the system.

Level of satisfaction directly affects agricultural insurance programs. Any slight dissatisfaction of an insured farmer affects both agricultural insurance purchase decision by himself and those by other farmers as potential insurance purchasers. Additionally, customer satisfaction is highly influential on future insurance purchase decisions (Taylor \& Baker, 1994). Data on customer satisfaction also provide valuable inputs to agricultural insurance companies. The perception of quality, value and farmer attitude towards agricultural insurance are highly influential on farmer satisfaction. Moreover, customer satisfaction is an important component of customer loyalty (Yazdanpanah et al., 2013). 
The objective of this study was to explore the satisfaction levels of insured apricot producers in Malatya province of Turkey- the world's largest provider of apricots-towards TARSIM insurance services. The results of the study indicated that efficient and rapid resolution of farmer problems and grant of ease for premium payments were the most influential factors affecting farmer satisfaction. Payment-related problems, in particular, were both indicated by structural equation modeling analysis and revealed to be the factor that deterred farmers from purchasing agricultural insurance in 2014.

The study findings on efficient and rapid resolution of farmer problems were in agreement with those of Yazdanpanah et al. (2013) who assessed farmer satisfaction towards agricultural insurance in Iran by using American Customer Satisfaction Index (ACSI). Insurance companies need to make an effort not only for increasing the number of insured farmers in the future, but also for resolving the complaints and problems of the currently insured farmers. Moreover, the studies to be conducted by agricultural publishing and counseling companies will contribute to proliferation of agricultural insurance programs. In this context, insurance companies and relevant public institutions are needed to work in collaboration (Sundar \& Ramakrishnan, 2015).

Payment-related problems which are influential on farmer satisfaction towards agricultural insurance also reveal perceptions towards premium amounts and pricing. Payment-related problems support the findings of Ginder et al. (2009) who reported that pricing was the most important factor influencing agricultural insurance purchase decisions by farmers. Priority needs to be given to the improvements on the dimensions of "pricing and payment policy" and "notification on insurance policy and collateral warranties". The low averages in these dimensions can be interpreted as general dissatisfaction in the population.

When the effects of satisfaction dimensions on overall satisfaction were analyzed, the dimension of "Notification on insurance policy and collateral warranties" ( 0.887 ; Table 7$)$ was evidently the most influential on overall satisfaction. Hence, it can be said that notification on insurance policy and collateral warranties has a higher influence on overall satisfaction. Based on these findings, it is recommended that improvements are made on notification of farmers on insurance policy and collateral warranties as first priority, followed by the improvements on damage compensations, as the second.

\section{References}

Akgül, A., \& Çevik, O. (2003). İstatistiksel Analiz Teknikleri. SPSS’te İşletme Yönetimi Uygulamaları. Emek Ofset Ltd. Şti., 456, Ankara.

Anonymous. (2007). IPCC 4. Değerlendirme Raporu. Intergovernmental Panel on Climate Change. Retrieved July 1, 2015, from http://www.ipcc.ch

Anonymous. (2014). Onuncu Kalkınma Planı, Bitkisel Üretim Özel İhtisas Komisyonu Raporu. Kalkınma Bakanlığı, Ankara.

Dragos, S. L., \& Codruta, M., (2014). An Econometric Approach to Factors Scrop Insurance in Romania. Ekonomie a Management, 17(1).

Eroğlu, E. (2005). Müşteri Memnuniyeti Ölçüm Modeli. E. İ.Ü. İşletme Fakültesi İşletme Dergisi, 34(1), 7-25.

FAO. (2015). Bitkisel Üretim Istatistikleri. Gıda ve Tarım Örgütü. Retrieved July 1, 2015, from http://www.fao.org/statistics/en

Gençtürk, M., Kalkan, A., \& Oktar, Ö. F. (2011). Bireysel Bankacılıkta Müşteri Memnuniyetini Etkileyen Faktörler: Burdur ve Isparta İllerinde Bir Uygulama. Süleyman Demirel Üniversitesi İktisadi ve İdari Bilimler Fakültesi Dergisi, 16(2), 59-77.

Ginder, M., Spaulding, A. D., Tudor, K. W., \& Winter, J. R. (2009). Factors Affecting Crop Insurance Purchase Decisions by Farmers in Northern Illinois. Agricultural Finance Review, 69(1), 113-125. https://doi.org/ 10.1108/00021460910960507

Gül Yavuz, G. (2011). Polatlı İlçesinde Üreticilerin Tartm Sigortası Yaptırmaya Karar Verme Sürecinde Etkili Olan Faktörlerin Analizi. Yayın No. 188, Mart 2011, Ankara.

Güneş, N. T. (2006). Frosthardiness of Some Turkish Apricot Cultivars during the Bloom Period. HortScience, $41,310-312$.

Kaska, N. (2006). Orchard Management InApricots. ISHS ActaHorticulturae 717: XIII International Symposiumon Apricot Breeding and Culture. 
Kumar, D. S., Barah, B. C., Ranganathan, C. R., Ranganathan, R., Gurunathan, S., \& Thirumoorthy, S. (2011). An Analysis of Farmers' Perceptionand Awareness towards Crop Insurance as a Tool for Risk Management in Tamil Nadu. Agricultural Economics Research Review, 24, 37-46.

Oliver, R. L. (1980). A Cognitive Model of the Antecedents and Consequences of Satisfaction Decisions. Journal of Marketing Research, XVII, 460-469. https://doi.org/10.2307/3150499

Saha, P., \& Zhao, Y. (2005). Relationship Between Online Service Quality and Customer Satisfaction: A Study in Internet Banking (Master's Thesis, Luleå University of Technology, MSc Programme in Electronic Commerce, Department of Business Administration and Social Sciences, Scandinavia).

Scherer, R. F., Wiebe, F. A., Luther, D. C., \& Adams, J. S. (1988). Dimensionality of Coping: Factor Stability Using the Ways of Coping Questionnaire. Psychological Reports, 62, 763-770. https://doi.org/10.2466/ pr0.1988.62.3.763

Schermelleh-Engel, K., Moosbrugger, H., \& Müller, H. (2003). Evaluating the Fit of Structurale Quationmodels: Tests of Significance and Descriptive Goodness-of-Fit Measures. Methods of Psychological Research, 8, 23-74.

Sundar, J., \& Ramakrishnan, L. (2015). A Study on Awareness, Purchase Benefits and Satisfaction Level towards Crop Insurance. Pacific Business Review International, 7(11), 38-45.

Tak, B. (2002). Kamu Kuruluşlarında Müşteri Odaklı Müşteri Odaklı Yönetim Anlayışına Geçiş Aracı Olarak Vatandaş Tatmin Araştırmaları. Süleyman Demirel Üniversitesi İktisadi ve İdari Bilimler Fakültesi Dergisi, 21(2), 143-159.

TARSIM. (2014). Faaliyet Raporu-2014. TARSiM Tarım Sigortaları Havuzu. Retrieved July 1, 2015, from http://www.tarsim.gov.tr/trsmWeb/index.jsp?_subpageid_=119

TARSIM. (2015). Kapsam ve Cari Uygulamalar 2015 Sunumu. TARSIM Tarım Sigortaları Havuzu. Retrieved July 1, 2015, from http://www.tarsim.gov.tr/trsmWeb/index.jsp?_subpageid_=119

Taylor, S. A., \& Baker, T. L. (1994). An Assessment of the Relationship between Service Quality and Customer Satisfaction in the Formation of Consumers' Purchase Intentions. Journal of Retailing, 70(2), 163-78. https://doi.org/10.1016/0022-4359(94)90013-2

TUIKK. (2015). Bitkisel üretim istatistikleri. Türkiye İstatistik Kurumu. Retrieved July 1, 2015, from http://www.tuik.gov.tr

Tümer, E. İ. (2011). Determination of Willing to Buy Crop Insurance: The Case of Tokat Province. J. of Agricultural Faculty of Atatürk Univ., 42(2), 153-157.

Yamane, T. (2009). In A. Esin, M. Akif Bakır, C. Aydın, \& E. Gürbüzsel (Eds.), Temel Örnekleme Yöntemleri. Literatür Yayınları İstanbul.

Yazdanpanah, M., Zamani, G. H., Hochrainer-Stigler, S., Monfared, N., \& Yaghoubi, J. (2013). Measuring Satisfaction of crop Insurance a Modified American Customer Satisfaction Model Approach Applied to Iranian Farmers. International Journal of Disaster Risk Reduction, 5, 19-27. https://doi.org/10.1016/ j.ijdrr.2013.04.003

\section{Copyrights}

Copyright for this article is retained by the author(s), with first publication rights granted to the journal.

This is an open-access article distributed under the terms and conditions of the Creative Commons Attribution license (http://creativecommons.org/licenses/by/4.0/). 